\title{
FEATURES OF UKRAINE'S PARTICIPATION IN INTERNATIONAL CONTRACTUAL RELATIONS
}

\author{
Tetiana Melnyk ${ }^{1}$, Liudmyla Kudyrko ${ }^{2}$, Liliia Samsonova ${ }^{3}$ \\ Kyiv National University of Trade and Economics, Ukraine
}

\begin{abstract}
The article highlights theoretical and practical aspects of economic rivalry escalation between countries in the process of deepening international economic relations, which are not mediated by investments. The purpose of the research is to summarize the empirical data and theoretical developments of the determinants, macroeconomic effects, and peculiarities of the countries' participation in international production and marketing cooperation through the format of non-investment contractual relations and investigate their potential for Ukrainian enterprises. The subject of the research is contractual relations as an instrument for incorporating the country's enterprises into global value chains. Methodology. Assessment of competitive advantages of countries integrated into the international subordinate production was carried out using the techniques of Vollrath T.L. and G. Lafay. Results. Based on the generalization of empirical data and theoretical studies on the latest trends in deepening economic rivalry among participants in international cooperative relations, there were found out factors of activation of non-investment forms of external expansion by TNCS, in particular, the exhaustibility of the extensive way of cross-border production development and investment, and the increased level of investment risks caused by permanent economic crises, political instability, corruption of local elites in the countries where TNC units are localized, regional military conflicts. Estimation of the level of comparative advantages according to Vollrath T.L. and G. Lafay approaches made it possible to identify the competitive positions of the producers of individual countries in the system of international cooperation. Estimation shows that among 41 tested countries, the most significant index of the identified comparative advantages in production under contract was demonstrated by the following countries: Bangladesh, Bolivia, Bosnia and Herzegovina, Paraguay, Romania, South Korea, Hungary, Poland. Additional testing according to the criteria values of the Lafay index confirmed the list of countries with the highest level of advantages Honduras, El Salvador, Nicaragua, Poland, Romania, Morocco, Malaysia, Hungary, Czech Republic, China, Bolivia, and Albania. Assessment of the state and potential for the development of international cooperative relations for Ukraine allowed us to identify a number of destructive factors, in particular, the lack of a relevant legal framework for contractual relations and the instability of the political and economic situation in the country. Practical implications. Possibilities for deepening the participation of Ukrainian enterprises in the contractual relationship system are related to their resource and technological comparative advantages, in particular, the availability of free production facilities, a relatively high level of production processes automation in comparison with selected African and Asian countries; availability of skilled labour force with its relatively low cost to the customer countries. Value/originality. The study of the Ukrainian enterprises' participation in the system of international cooperation and the definition of sectoral specifics in the use of cross-border contractual relations make it possible to identify the problems of macroeconomic effects for the national economy.
\end{abstract}

Key words: contractual relations, international cooperation, global production networks, subordinate production, theory of comparative advantages, Ukraine.

JEL Classification: F01, F02, F14, F23

\footnotetext{
Corresponding author:

${ }^{1}$ DInternational Economic Relations Department, Kyiv National University of Trade and Economics.

E-mail: melnikknteu998@gmail.com

${ }^{2}$ International Economic Relations Department, Kyiv National University of Trade and Economics.

E-mail: 1.kudirko@ukr.net

${ }^{3}$ International Economic Relations Department, Kyiv National University of Trade and Economics.

E-mail: samsonova.lilija.gov.ua@ukr.net
} 


\section{Introduction}

The current state of the world economy can be characterized by intensive interpenetration and intertwining of trade and production relations between countries at various levels of management, incl. corporate. Transnational companies are actively forming new localization centres for their own production, expanding the range of the location of production facilities in new foreign markets. At the same time, the international practice of cross-border movement of capital and production indicated limited traditional investment methods of external expansion that is determined by a number of factors. Firstly, the number of countries that can be the object of investment is reduced annually, so the extensive development of cross-border production and investment is exhaustive; Secondly, as the last decade shows, in a global recession and the turbulence of global and national development, direct investment is associated with a growing level of risk: permanent economic crises, political instability, corruption of local elites, military conflicts, and other factors are responsible for this process.

In this regard, more and more companies are beginning to use methods of organizing their own international production, which are alternative to direct investments. Moreover, the tightening competition in the world markets of final goods and services has been transformed into an intensification of economic competition among intermediate products producers. Countries compete for the possibility of localizing production at any stage of the technological process, as this issue directly relates to the increase of jobs and its share in value added in global production and distribution networks. The peculiarity of the new stage of the world economic development expresses the high level of the probability of its reformatting in terms of changing key centres of investment, intermediate consumption, and final production, which is connected with the desire of the governments to intensify production on the national territory. The established networks of corporate and non-corporate TNCs' relations can be restructured by removing parts of regions and countries from the global cooperation system in case production is returned to the TNC home-country.

Ukraine is also included in the system of international contractual relations as an executive country in the processing of intermediate products. There are also risks of production activities decreasing in case of limited non-resident companies orders. Now, the scientific and practical problem of assessing the backgrounds and effects of the participation of enterprises of individual national economies in the system of international cooperation is being updated through the mechanism of contractual agreements that are not related to investments. After all, this understanding allows us to assess more critically the feasibility of institutional assistance in localizing production processes and technological stages in the territory of individual states both in terms of its advantages for national economic development and in the plane of destructive impact.

The purpose of the research is to summarize the empirical data and theoretical developments on the factors, macroeconomic effects, and peculiarities of the countries' participation in the relations of international production and marketing cooperation through the format of non-investment contractual relations and the disclosure their potential for Ukrainian enterprises. To achieve the goal, it is necessary to solve the following tasks: to study the theoretical foundations about the specifics of the countries' participation in international cooperation through the format of contractual relations, to analyse the participation of countries in international cooperation on the basis of statistical data, to identify the macroeconomic effects of countries' participation in the relations of international production and marketing cooperation, and to determine positive and the negative effects of Ukrainian enterprises' participation in international contractual relations. The methodology of the study. Assessment of the competitive advantages of countries integrated into the international subordinate production was carried out using the approaches of Vollrath T.L. and G. Lafay to identify the level of comparative advantages of individual countries in terms of international contract manufacturing.

\section{Contractual relations in the system of international cooperation}

The participation of enterprises integrated into the international system of supply-and-demand cooperation acts as a driver of structural changes in many economies of the world, while ties deepening led to both positive and negative changes. Empirical studies show that access to a whole range of foreign intermediate goods, which can be parts and components or any other details used in the production of end-use products, at competitive prices is crucial for improving productivity in both the economically developed countries and in dynamically developing, particularly in India and China (Miroudot et al., 2009).

Empirical studies also confirm the fact that enterprisesexecuters of manufacturing services and works under the order of non-residents in developing countries or countries with transitive economies can achieve a greater success in their own markets due to association with higher standards of production organization and business processes that are regulated by foreign orders.

The largest exporters and importers of intermediate goods are unchanged from 2010 to 2014 . There remain 28 countries of the European Union with an indicator of about $30 \%$ of total exports/imports of intermediate goods, the second place is occupied by China, the third by the United States. These countries import and export 
more than $60 \%$ of the value of intermediate goods in the world. On average, the rest block of the countries (per one country) account for between 2.5 and 0.1 percent of the world of intermediate goods turnover (World Bank, 2014). This statistics confirms the fact that countries with different levels of development are involved in the system of international cooperation, the most active from which are the EU states, the USA (acting as leading countries or as contractor countries), and developing countries, mainly from the Asian region. The PRC occupies a special place, positioning itself as a country with dynamic economic development. The contractual relations of Chinese enterprises with foreign customers have become a factor both in the creation of new and development of existing industries in the PRC. Acquiring rapidly foreign experience and technology, there were established a huge number of companies that began to produce end-use goods that compete with the leading companies from economically developed countries in the world market.

An analysis of international experience shows that a business model or strategy of a transnational corporation can incline a company to use a certain type of contractual relations in the system of international production or marketing cooperation. So, in case of franchising, which provides that business model is built on the use of the industrial or intellectual property as the core competence, an exclusive franchise is used for distribution in both domestic and foreign markets (Reid, Mark, 2008). In pharmacology, the trend towards outsourcing of production stages along the entire value chain encourages TNCs to use this format of contractual relationships as contract production. In particular, according to the outsourcing strategy of the international giant Pfizer, contractual relations are being formed with about 150 producers (on contract manufacturing terms) all over the world. From 2003 to 2008, Pfizer reduced the number of its own enterprises by almost 50\% (up to 46 plants). The main considerations in choosing outsourcing were: the supply possibility, the capacities flexibility, cost competitiveness and technology, as well as ensuring the integrity/reliability of the supply chain, product quality, and regulatory compliance (website www.pfizer.com).
Peculiarities of contract production in some industries, in particular, automotive and electronics, are determined by the fact that the contractual relationship model is matured, and the contract producers turned from suppliers to large TNCs with strong competencies and cost advantages. For global automotive brands, investing in their own intermediate production capacity is impractical. For example, Denso (Japan), automotive parts manufacturer and Foxconn (Taiwan Province of China), however, electronics contract manufacturers, have huge volumes of operations in many locations, as well as investing heavily in research (Cattaneo and et al., 2010).

\section{Countries' competitiveness in contract manufacturing}

Contractual relations are the subject of the theory of comparative advantages; therefore, in assessing the extent to which the countries have used contractual relations in their international activities, it was decided to use the methodology for assessing the level of competitiveness of certain types of contractual relations across the world. We use the approach of Vollrath T.L. index of the revealed comparative advantages RCA (Revealed Comparative Advantage) (Vollrath, 1991) and G. Lafay - index of LFI (Lafay, 1992). Among the existing types of contractual relations, there was selected the contract manufacturing. This choice is justified by the availability of relevant statistics for selected countries for the selected period, which is provided by the IMF database from the countries' balance of payments. The indices of the revealed comparative advantages and the LFI index for contract manufacturing are given in Tables 1 and 2.

The value of the RCA index in contract manufacturing allows ranking countries from the sample as having the greatest advantages: Bangladesh, Bolivia, Bosnia and Herzegovina, Honduras, Paraguay, Romania, Republic of Korea, Hungary, Poland. A country that does not have any comparative advantages according to calculations is Peru. Other countries with a score of 0.1 to 5.0 can be considered as those that have comparative advantages in contract manufacturing.

Table 1

The index of comparative advantages of contract manufacturing for selected countries, 2007-2015 years

\begin{tabular}{|c|c|c|c|c|c|c|c|c|c|c|}
\hline \multirow{2}{*}{ № } & \multirow{2}{*}{ Countries } & \multicolumn{9}{|c|}{ RCA - Index of the revealed comparative advantages } \\
\hline & & 2007 & 2008 & 2009 & 2010 & 2011 & 2012 & 2013 & 2014 & 2015 \\
\hline 1 & Albania & 4,6 & 4,6 & 3,4 & 6,1 & 7,1 & 6,5 & 4,5 & 6,1 & 7,5 \\
\hline 2 & Australia & 0,0 & 0,0 & 0,0 & 0,0 & 0,0 & 0,0 & 0,0 & 0,0 & 0,0 \\
\hline 3 & Austria & 2,8 & 2,3 & 2,1 & 1,7 & 1,9 & 1,3 & 2,6 & 3,1 & 3,2 \\
\hline 4 & Azerbaijan & 4,3 & 1,5 & 4,6 & 4,1 & 2,2 & 2,0 & 0,0 & 0,0 & 0,0 \\
\hline 5 & Bangladesh & 11,8 & 4,4 & 0,4 & 0,5 & 0,5 & 0,5 & 0,5 & 0,7 & 0,6 \\
\hline 6 & Belarus & 5,4 & 3,3 & 2,9 & 2,4 & 2,4 & 2,0 & 2,0 & 1,7 & 1,4 \\
\hline 7 & Belgium & 4,4 & 3,4 & 2,9 & 2,9 & 3,3 & 3,5 & 2,4 & 2,4 & 2,7 \\
\hline 8 & Bolivia & 13,7 & 10,7 & 10,0 & 8,3 & 6,1 & 3,8 & 3,1 & 2,7 & 3,1 \\
\hline 9 & Bosnia and Herzegovina & 49,2 & 34,1 & 18,7 & 22,4 & 26,1 & 22,1 & 21,1 & 24,9 & 22,7 \\
\hline
\end{tabular}


Vol. 4, No. 1, 2018

End of Table 1

\begin{tabular}{|c|c|c|c|c|c|c|c|c|c|c|}
\hline 10 & China & 9,0 & 6,9 & 7,5 & 7,1 & 5,6 & 5,0 & 4,2 & 3,1 & 2,9 \\
\hline 11 & Costa Rica & 5,9 & 4,4 & 6,2 & 6,5 & 7,3 & 7,1 & 6,0 & 4,1 & 1,8 \\
\hline 12 & Côte d'Ivoire & 8,2 & 6,8 & 7,1 & 6,3 & 6,5 & 5,9 & 6,1 & 0,0 & 0,0 \\
\hline 13 & Croatia & 4,7 & 3,8 & 2,6 & 2,6 & 2,4 & 2,6 & 1,9 & 2,0 & 2,0 \\
\hline 14 & Czech Republic & 4,8 & 3,7 & 3,0 & 2,6 & 2,0 & 2,8 & 3,7 & 4,3 & 4,6 \\
\hline 15 & Dominican Republic & 26,9 & 19,3 & 16,5 & 1,3 & 2,5 & 2,3 & 0,7 & 0,7 & 0,8 \\
\hline 16 & El Salvador & 14,8 & 13,1 & 15,1 & 16,2 & 15,9 & 12,3 & 12,0 & 10,5 & 13,0 \\
\hline 17 & France & 2,0 & 1,9 & 1,8 & 1,7 & 2,0 & 2,5 & 2,7 & 3,5 & 3,9 \\
\hline 18 & Germany & 2,4 & 1,7 & 1,6 & 1,8 & 1,9 & 1,7 & 1,4 & 1,7 & 1,8 \\
\hline 19 & Honduras & 41,8 & 30,2 & 30,5 & 32,6 & 31,6 & 27,9 & 32,0 & 34,5 & 38,0 \\
\hline 20 & Hungary & 5,5 & 3,3 & 2,6 & 2,8 & 3,5 & 4,4 & 4,6 & 5,6 & 6,4 \\
\hline 21 & Iceland & 10,3 & 8,6 & 6,0 & 7,7 & 7,2 & 6,1 & 5,9 & 3,1 & 2,1 \\
\hline 22 & India & 0,0 & 0,0 & 0,0 & 0,0 & 0,0 & 0,0 & 0,0 & 0,1 & 0,1 \\
\hline 23 & Indonesia & $-4,9$ & $-3,2$ & $-3,0$ & $-0,5$ & 1,9 & 0,6 & 0,7 & 0,8 & 0,7 \\
\hline 24 & Italy & 0,9 & 2,9 & 3,1 & 3,3 & 2,8 & 2,7 & 2,8 & 2,8 & 2,9 \\
\hline 25 & Republic of Korea & 4,8 & 3,6 & 4,9 & 4,9 & 5,7 & 5,2 & 5,2 & 5,4 & 5,9 \\
\hline 26 & Lithuania & 3,6 & 2,9 & 5,7 & 6,0 & 3,8 & 2,9 & 2,8 & 2,4 & 2,2 \\
\hline 27 & Luxembourg & 0,3 & 0,1 & 0,1 & 0,1 & 0,1 & 0,1 & 0,1 & 0,1 & 0,1 \\
\hline 28 & Malaysia & 0,0 & 0,0 & 0,0 & 3,6 & 3,3 & 2,9 & 2,7 & 3,0 & 3,2 \\
\hline 29 & Morocco & 11,2 & 7,7 & 10,8 & 9,5 & 7,5 & 7,4 & 5,5 & 6,2 & 6,1 \\
\hline 30 & Netherlands & 0,0 & 0,0 & 0,0 & 3,4 & 4,0 & 4,0 & 4,1 & 4,0 & 3,9 \\
\hline 31 & Nicaragua & 24,6 & 17,9 & 19,0 & 21,1 & 22,7 & 23,1 & 24,6 & 27,6 & 26,6 \\
\hline 32 & Paraguay & 32,9 & 8,0 & 5,2 & 7,8 & 9,2 & 7,9 & 8,3 & 10,3 & 10,0 \\
\hline 33 & Peru & $-11,7$ & $-8,8$ & $-5,0$ & $-10,7$ & $-15,5$ & $-13,9$ & $-10,8$ & $-5,8$ & $-6,3$ \\
\hline 34 & Poland & 3,2 & 1,9 & 2,6 & 2,7 & 3,0 & 3,1 & 4,4 & 5,2 & 5,5 \\
\hline 35 & Portugal & 1,8 & 1,1 & 0,9 & 1,0 & 1,1 & 1,2 & 1,3 & 1,2 & 1,0 \\
\hline 36 & Romania & 19,5 & 11,6 & 9,2 & 8,8 & 9,8 & 8,7 & 10,5 & 11,5 & 11,1 \\
\hline 37 & Russian Federation & 2,5 & 2,1 & 1,9 & 1,9 & 1,6 & 1,3 & 1,3 & 1,0 & 0,9 \\
\hline 38 & Slovakia & 0,0 & 1,5 & 2,3 & 2,6 & 2,8 & 2,5 & 2,2 & 2,4 & 2,0 \\
\hline 39 & Slovenia & 0,4 & 2,6 & 1,6 & 1,8 & 1,7 & 2,9 & 2,2 & 1,8 & 1,5 \\
\hline 40 & Switzerland & 0,0 & 0,6 & 0,6 & 0,4 & 0,4 & 0,6 & 0,5 & 0,7 & 0,7 \\
\hline 41 & United Kingdom & 0,1 & 0,1 & 0,1 & 0,2 & 0,2 & 0,2 & 0,9 & 0,8 & 0,8 \\
\hline 42 & Ukraine & 4,8 & 3,5 & 3,4 & 4,0 & 5,0 & 5,3 & 4,9 & 5,0 & 5,3 \\
\hline
\end{tabular}

Calculated by the author on the basis of balance of payments

Table 2

The LFI Index, calculated for contract manufacturing (countries of the world), 2007-2015 years

\begin{tabular}{|c|c|c|c|c|c|c|c|c|c|c|}
\hline \multirow{2}{*}{$№$ № } & \multirow{2}{*}{ Countries } & \multicolumn{9}{|c|}{ LFI - Lafay index } \\
\cline { 2 - 11 } & 2007 & 2008 & 2009 & 2010 & 2011 & 2012 & 2013 & 2014 & 2015 \\
\hline 1 & Albania & 3,81 & 4,82 & 3,33 & 5,65 & 6,65 & 6,09 & 4,29 & 5,31 & 5,82 \\
\hline 2 & Australia & 0,02 & 0,02 & 0,06 & 0,04 & 0,02 & 0,01 & 0,01 & 0,01 & 0,01 \\
\hline 3 & Austria & $-1,09$ & $-1,13$ & $-0,50$ & $-0,99$ & $-1,00$ & $-0,98$ & $-1,53$ & $-1,49$ & $-1,41$ \\
\hline 4 & Azerbaijan & 5,23 & 2,45 & 6,21 & 5,28 & 3,09 & 2,66 & 0,02 & 0,00 & 0,01 \\
\hline 5 & Bangladesh & 5,25 & 3,11 & 0,52 & 0,70 & 0,71 & 0,72 & 0,77 & 0,93 & 0,82 \\
\hline 6 & Belarus & 3,33 & 2,58 & 2,13 & 1,78 & 1,63 & 1,41 & 0,99 & 1,05 & 0,94 \\
\hline 7 & Belgium & 2,70 & 3,04 & 2,42 & 2,01 & 2,03 & 1,66 & 1,27 & 1,36 & 1,36 \\
\hline 8 & Bolivia & 14,10 & 18,63 & 14,95 & 10,55 & 7,30 & 5,10 & 4,33 & 3,54 & 3,50 \\
\hline 9 & Bosnia and Herzegovina & 29,22 & 31,23 & 11,31 & 9,06 & 11,57 & 10,19 & 9,38 & 11,29 & 9,04 \\
\hline 10 & China & 7,94 & 8,01 & 8,71 & 8,08 & 6,49 & 6,19 & 5,31 & 3,60 & 3,34 \\
\hline 11 & Costa Rica & 2,42 & 2,32 & 3,63 & 3,86 & 3,80 & 3,79 & 2,97 & 1,91 & 0,85 \\
\hline 12 & Cote d'Ivoire & 1,15 & 1,46 & 1,91 & 1,46 & 2,45 & 2,47 & 2,74 & 0,00 & 0,00 \\
\hline 13 & Croatia & $-1,13$ & $-1,08$ & 0,64 & $-0,07$ & 0,21 & 0,08 & 0,44 & 0,67 & 0,67 \\
\hline 14 & Czech Republic & 2,37 & 2,12 & 2,21 & 1,87 & 1,16 & 1,40 & 2,45 & 2,70 & 2,53 \\
\hline 15 & Dominican Republic & 9,66 & 9,75 & 8,07 & 1,05 & $-0,33$ & $-0,28$ & 0,42 & 0,40 & 0,43 \\
\hline 16 & El Salvador & 11,83 & 13,53 & 14,00 & 14,58 & 14,09 & 11,05 & 10,22 & 8,08 & 9,58 \\
\hline 17 & France & 0,27 & 0,39 & 0,64 & 0,68 & 0,98 & 0,63 & 0,42 & 0,27 & 0,25 \\
\hline 18 & Germany & 0,20 & 0,30 & 0,47 & 0,44 & 0,31 & 0,20 & 0,15 & 0,24 & 0,17 \\
\hline
\end{tabular}


End of Table 2

\begin{tabular}{|l|c|c|c|c|c|c|c|c|c|c|}
\hline 19 & Honduras & 26,76 & 25,84 & 22,19 & 24,63 & 26,00 & 26,04 & 27,61 & 27,50 & 28,22 \\
\hline 20 & Hungary & 2,46 & 2,45 & 1,79 & 1,90 & 2,05 & 3,09 & 2,99 & 3,31 & 3,67 \\
\hline 21 & Iceland & 8,80 & 9,03 & 5,41 & 6,83 & 6,50 & 5,80 & 5,02 & 2,48 & 1,52 \\
\hline 22 & India & 0,00 & 0,00 & 0,00 & 0,00 & 0,00 & 0,01 & 0,00 & 0,05 & 0,04 \\
\hline 23 & Indonesia & $-5,69$ & $-4,60$ & $-4,10$ & $-0,61$ & 2,39 & 0,81 & 0,90 & 0,88 & 0,79 \\
\hline 24 & Italy & 0,07 & 0,45 & 0,58 & 0,91 & 0,50 & 0,44 & 0,47 & 0,20 & 0,25 \\
\hline 25 & Republic of Korea & $-0,97$ & $-1,52$ & $-2,55$ & $-2,22$ & $-3,36$ & $-3,00$ & $-2,50$ & $-2,39$ & $-2,34$ \\
\hline 26 & Lithuania & 2,26 & 2,55 & 4,77 & 4,88 & 3,04 & 2,42 & 0,25 & 0,64 & 1,43 \\
\hline 27 & Luxembourg & 0,05 & 0,04 & 0,04 & 0,01 & 0,00 & 0,01 & 0,01 & 0,02 & 0,03 \\
\hline 28 & Malaysia & 0,01 & 0,00 & 0,00 & 3,66 & 3,34 & 3,14 & 2,74 & 2,84 & 3,02 \\
\hline 29 & Morocco & 5,42 & 5,26 & 7,32 & 6,69 & 5,57 & 5,55 & 3,89 & 4,20 & 4,03 \\
\hline 30 & Netherlands & 0,00 & 0,00 & 0,00 & $-0,59$ & $-1,25$ & $-1,27$ & $-1,25$ & $-1,33$ & $-1,39$ \\
\hline 31 & Nicaragua & 21,86 & 19,60 & 18,31 & 19,32 & 20,37 & 20,86 & 22,75 & 22,62 & 19,57 \\
\hline 32 & Paraguay & 0,00 & 0,00 & 0,00 & 0,00 & 0,00 & 0,00 & 0,00 & 0,00 & 0,00 \\
\hline 33 & Peru & 0,00 & 0,00 & 0,00 & 0,00 & 0,00 & 0,00 & 0,00 & 0,00 & 0,00 \\
\hline 34 & Poland & 2,01 & 1,60 & 2,15 & 2,30 & 2,38 & 2,64 & 3,32 & 3,57 & 3,30 \\
\hline 35 & Portugal & 0,91 & 0,65 & 0,60 & 0,64 & 0,65 & 0,68 & 0,66 & 0,61 & 0,51 \\
\hline 36 & Romania & 12,93 & 9,81 & 7,22 & 6,68 & 7,75 & 6,53 & 7,29 & 7,05 & 6,31 \\
\hline 37 & Russian Federation & 1,95 & 2,25 & 1,99 & 2,13 & 1,70 & 1,52 & 1,40 & 0,98 & 0,85 \\
\hline 38 & Slovakia & 0,00 & 1,08 & 1,95 & 1,57 & 1,50 & 1,16 & 0,97 & 1,07 & 0,97 \\
\hline 39 & Slovenia & $-0,37$ & 1,17 & 0,69 & 0,44 & 0,19 & $-0,88$ & 0,59 & 0,81 & 0,56 \\
\hline 40 & Switzerland & $-0,03$ & 0,54 & 0,53 & 0,40 & 0,37 & 0,47 & 0,47 & 0,49 & 0,58 \\
\hline 41 & United Kingdom & 0,05 & 0,09 & 0,09 & 0,11 & 0,11 & 0,12 & 0,29 & 0,24 & 0,24 \\
\hline 42 & Ukraine & 3,62 & 3,51 & 3,15 & 3,48 & 3,99 & 4,47 & 4,15 & 4,14 & 4,04 \\
\hline
\end{tabular}

Calculated by the author on base of Balance of payments

According to the estimated values of the LFI index, the larger its value, the higher the level of benefits in the country. Countries with high levels of benefits include Honduras, El Salvador, Nicaragua, Poland, Romania, Morocco, Malaysia, Hungary, Czech Republic, China, Bolivia, and Albania. The lack of competitiveness in production under contract is demonstrated by the Republic of Korea, Austria, and other countries from the sample, which is less than zero.

The balance of payments' statistics shows that the increase in licensing activity in developing countries is spontaneous and is not stable, while developed countries are consistently leaders in licensing. In the process of choosing a country for the implementation of a license, royalties play a decisive role and, on this basis, developing countries and countries with transitional economies in modern reality pay a quarter of the global royalties. The geographic distribution of licensing is wide enough, although South, East, and South-East Asia cover about $70 \%$ of developing countries and countries with transition economies, followed by Latin America and the Caribbean, SouthEast Europe, Africa, and West Asia. In each region, licensing activity is concentrated in several countries, for example, South Africa and Egypt in Africa, Brazil and Argentina in Latin America, and Turkey in Western Asia. The licensing case is more developed in Western and South-West Asia, in Singapore, China, and the Province of Taiwan.

\section{Ukraine's participation in international contractual relations}

Pointing out the peculiarities of Ukraine's integration into the system of international cooperation relations, it is important to note that it has experience of deep industrial and marketing cooperation within the framework of the unified national economic complex of the USSR. After having got independent, Ukrainian enterprises began to enter into the production systems of European and a part of Asian markets, whose companies act as contract customers. For Ukraine, the complexity of the formation of contractual relations is not only consisting of the fact that this is a new phenomenon both in international and national territories but also because there is a lack of experience in building contractual relations with foreign counterparties. Obviously, Ukrainian companies take a weaker position on many aspects related to contractual relations, although in some areas it is possible to observe the positive consequences of such international cooperation.

Complications for the development of international cooperation are led by the fact that now in Ukraine there is no legislative basis that would resolve all controversial and risky issues of contractual relations. Besides, the country generally experiences an unstable political and economic situation, which affects the performance of all spheres of business, and not only activities based on international contractual relations. On the other hand, 
foreign customers of contractual relations are attracted to Ukraine with unconditional advantages: firstly, the availability of free production facilities, the automation level of which is much higher than the underdeveloped African and Asian countries; secondly, a skilled workforce and, thirdly, it is the low cost of quality labour in relation to labour costs in the contracting countries. Given the historical aspects of the contractual relations formation and the specifics of the collection, processing, and submission of information in Ukraine, we were able to conduct an analysis of the involvement of Ukrainian enterprises in international cooperative relations, taking into account their specific branch structure.

By the mode-sectoral structure is understood a combination of contractual relations by types/sector, where a particular type is used in large volumes. The generalization of empirical and statistical information allowed us to distinguish the following typical formats of contractual relations between Ukrainian enterprises (executors) and foreign contractors (customers): for apparel industry - contract manufacturing (tolling, processing of raw materials); in the hotel and restaurant industry - franchising; in the field of information technology and business process management outsourcing; in the field of research and development and the implementation of patents, utility models, and other intellectual property products - licensing. Contract management is almost not common in Ukraine as a service for export. Also considering peculiarities of land resources management and economic complex in Ukraine, contract farming exists in very limited forms.

Analysis of data from the State Statistics Service for 2013-2016 showed that the key export positions among contractual relations are operations based on give-and-take raw materials (with a tendency to increase) in chemical products (commodity group VI) and apparel (product groups VII, XI, XII, XX) industries, machinery (commodity group XVI), as well as goods of Group X, of which the share made from customer-supplied raw materials, is more than $26 \%$ and other productions (commodity group XX). Thus, in Ukraine, in re-export positions in which the share of products made from customer-supplied raw materials exceeds $50 \%$, only apparel industry product, that is, commodity groups VIII, XI, and XII. At the same time, there is deepening negative tendency of the share of production from the give-and-take raw materials in the machine-building exports, whose share in the commodity structure of Ukrainian exports for this period, on the contrary, it decreased by $0.96 \%$. The imported raw materials for apparel industry (commodity groups VIII and XI) prevails, with a tendency to increase during the considered period. In addition to these goods, a significant share in the structure of imports is occupied (with a decline in 2016): various industrial goods (commodity group $\mathrm{XX}$ ), machinery, equipment and mechanical appliances (commodity group XVI) and polymeric materials, plastics and goods thereof (commodity group VII).

As a result, the reduction of commodity imports to Ukraine (primarily due to the growth of the foreign exchange rate) creates additional opportunities for the development of national industries in the direction of import substitution of goods for both final and intermediate consumption. However, the intensive growth in imports of tolling raw materials threatens the further functioning of individual industries (primarily textile and machine building).

It is important to focus on certain financial aspects of the domestic legislation, in fact, make it impossible to re-direct domestic contractor enterprises to seek other formats of activity as a subject of foreign economic activity, and the country's budget is deprived of the tax incomes. Expenses for operations with give-andtake raw materials for an entrepreneur-performer are recognized in the amount not exceeding the income received from such sale/exchange. Therefore, losses under tolling services by the Fiscal Code are not allowed (Regulation (Standard) of Accounting 21). Processing of customer-made raw materials imported by a nonresident to the customs territory of Ukraine (subject to further exportation of the products of its processing from the territory of Ukraine) is subject to VAT at a zero rate (Instructions for the application of the plan of accounts for the bookkeeping of assets, capital, liabilities and business operations of enterprises and organizations, 1999).

At the same time, a zero VAT rate in respect of works (services) for the processing of tolling raw materials is used both by the enterprise, which is determined by the main contractor for the contract on processing of the customer's raw materials, and for the enterprise involved in the technological process associated with the processing of tolling raw materials into finished products, if it is indicated in the contract for the processing of tolling raw materials. And last, the revenue for the taxation purposes of the processor usually arises only at the cost of its services for processing customersupplied raw materials.

Summarizing the above, we can draw the following conclusions: firstly, the import duty rate and VAT for give-and-take raw materials is $0 \%$; secondly, services for the processing of material resources are also not subject to VAT; thirdly, only the income of the processor from the services provided is the basis for the appearance of tax liabilities. Thus, only the tax on the results of the activity of processing enterprises settles in the country's budget.

International experience in the use of contractual relations as an instrument for incorporating the national business into the global production and marketing cooperation system confirms the possibility for the executing companies both to climb the technological 
progress stages and to preserve their production capabilities in the weakest low-yielding chains of global value creation. This depends upon country's competitive advantages in locating production processes, institutional support for structural changes in the national economy, the course of economic competition between key producers and customers of international contractual services.

\section{Conclusions}

Summarizing the conducted research, we can make the following generalizations:

- the countries' participation in the system of international cooperation, including the format of contractual relations not related to investment, contains a number of opportunities in terms of increasing the rate of employment, simplified access to external markets, increasing the level of organizational and technological culture of production processes, nevertheless it is also accompanied by certain challenges, such as: the influence of endogenous factors on the development of the level of manufacturability of national production, the localization of low profitable production processes on the economy national territory; high level of dependence of the national economic dynamics of demand of non-residents;

- an assessment of the level of countries' competitive advantages, taking into account their participation in international contractual relations through subordinate production, has shown the variability of the status of countries as participants in international cooperation: a significant level of comparative advantages can be enjoyed by a country from a group of states with a high level of economic development and developing country or with a transitional economy;

- the opportunities for deepening the participation of Ukrainian enterprises in the contractual relationship system are related to their resource and technological comparative advantages, in particular, the availability of free production capacity, a relatively high level of automation of production processes for selected African and Asian countries; the availability of skilled labour force with the background of its low cost in comparison with the countries-customers.

Further studies of this problem relate to a more in-depth analysis of the macroeconomic effects of Ukraine's participation in the international cooperation system and the identification of sectoral specifics in the use of cross-border contractual relationships.

Gratitude. The preparation and writing of the article became possible with the support and funding of the research topic "Global imperatives of the international production development \#648/20" by the Ministry of Education and Science of Ukraine, which was carried out at the International Economic Relations Department of KNUTE in 2016-2018.

\section{References:}

Cattaneo, Olivier, Gary Gereffi and Cornelia Staritz (eds.) (2010). Global Value Chains in a Postcrisis World: A Development Perspective. Washington, DC: The World Bank.

Instrukciya pro zastosuvannya Planu rakhunkiv bukhgalterskogo obliku aktyviv, kapitalu, zobovyazan i gospodarskykh operacij pidpryyemstv i organizacij [Instructions for the application of the plan of accounts for the bookkeeping of assets, capital, liabilities and business operations of enterprises and organizations]. (1999). Kyiv: Ministry of Finance of Ukraine from November 30, No 291. http://dtkt.com.ua. Retrieved from: http://dtkt.com.ua/show/2cid06881.html. [in Ukrainian]

Lafay, G. (1992). The Measurement of Revealed Comparative Advantages. International Trade Modeling, London, 209-237.

Miroudot, S. Lanz, R. and A. Ragoussis (2009). Trade in intermediate goods and services. OECD Trade Policy Working Paper, 93. Retrieved from: http:/ / www.oecd.org/dataoecd/47/14/44437205.pdf

Polozennja (standart) buchhalterskoho obliku 21 «Vlyv zmin valjutnych kursiv» [Regulation (standard) of accounting 21 "The impact of changes in exchange rates"]. http://zakon1.rada.gov.ua. Retrieved from: http://zakon1.rada.gov.ua/laws/show/z0515-00. [in Ukrainian]

Reid, Mark (2008). A case study analysis of the Benetton supply chain. MBA paper, University of Greenwich Business School.

Site of the International Monetary Fund. (2007-2015). Balance of Payments Standard Presentation by Indicator: Current Account, Goods and Services, Services, Manufacturing Services on Physical Inputs Owned by Others, Debit-Credit. http://data.imf.org. Retrieved from: http://data.imf.org/regular.aspx?key=61468208

Site of the Pfizer company. www.pfizer.com. Retrieved from: www.pfizer.com.

Site of the World Bank. (2014). World Intermediate goods Exports By Country and Region. https://wits.worldbank. org. Retrieved from: https://wits.worldbank.org/CountryProfile/en/Country/WLD/Year/2014/TradeFlow/ Export/Partner/all/Product/UNCTAD-SoP2

Vollrath T.L. (1991). A theoretical evaluation of alternative trade intensity measures of revealed comparative advantage. Review of World Economics, 127, 265-280. 